\title{
Tarihsellik: Tarihte Olmak ya da Tarihsiz OImak
}

\author{
Araștırma makalesi / Research article
}

Şerket KOTAN*

\section{Historicity: to be in History or to be without History}

Citation/C): Kotan, Şevket, (2019). Historicity: to be in History or to be without History, Milel ve Nihal, 16 (2), 251-264.

Abstract: This article will examine the concept of historicist Islam, a new phenomenon that emerged in the modern era, in relation with the foundational discourses and its philosophical and religious affiliations. As a thesis for this research, we will argue that the historicist Islam is only indirectly related to the ontological historicity from the philosophical point of view and to the Islamic tradition of scholarship from religious aspect. Rather the historicist Islam is directly rooted in the Islamic modernism as this tendency of thought is related to positivist rationalism philosophically, and reformist discourses in terms of religious thought. Furthermore, this study focuses on the fact that historicist Islam is a discourse of salvation like other Islamic though movements that emerged in the modern era, and that historicist Islam is classified as a contemporary period 'Theology of Salvation', with the emphasis on the fact that the nature of salvation discourse doesn't allow it to be scientific in its interpretation.

Keywords: Historicist Islam, Being in History, Being without History, Theology of Liberation/Salvation, Islamic Modernism.

* Doç. Dr., İstanbul Üniversitesi, İlahiyat Fakültesi, Tefsir Anabilim Dalı [sevketkotan@yahoo.com] ORCID: 0000-0002-6491-7235. 
Atıf/C: Kotan, Şevket, (2019). Tarihsellik: Tarihte Olmak ya da Tarihsiz Olmak, Milel ve Nihal, 16 (2), 251-264.

Öz: Bu makale, yeni bir olgu olarak modern dönemde ortaya çıkan "tarihselci İslam"ı, temel söylemleri, felsefi ve dini mensubiyeti itibarıyla inceleyecektir. Tez olarak da "tarihselci İslam"ın felsefi bakımdan ontolojik tarihselliğe ve dini bakımdan da İslam ilim geleneğine mensubiyetinin ancak dolaylı olduğunu, zira bu düşünce eğiliminin felsefi bakımdan pozitivist rasyonalizme ve dini bakımdan da reformist söylemlere, dolayısıyla da İslam modernizmine mensup olduğunu savunacaktır. Ayrıca bu çalışmada, "tarihselci İslam"ın modern dönemde ortaya çıkan diğer İslami düşünce akımları gibi bir kurtuluş söylemi olduğu üzerinde durularak "tarihselci İslam" bir çağdaş dönem 'kurtuluş teolojisi' olarak vasıflandırılacak ve kurtuluş söylemi karakterinin onu yorumda bilimsel olmaktan uzaklaştırdığı vurgulanacaktır.

Anahtar Kelimeler: Tarihselci İslam, Tarihte olmak, Tarihsiz olmak, Kurtuluş Teolojisi, İslam Modernizmi.

Tarihsellik konusunun insan-tarih ilişkisini, yani tarihteki insanı (Dasein) ve bunun etrafındaki meseleleri ele almak yerine Kur'an'ın tarihselliğini ele alarak metafizik bir tartışmaya dönüşmesi İslam ilahiyatı açısından bir talihsizlik olarak not edilmelidir. XVIII. yüzyıldan itibaren konunun süreç içerisinde şekillenen arka planına bakıldığında bu tartışma içerisindeki esas meselenin akıl, insan ve insan-tarih ilişkisi olduğu görülmektedir. Zaten tarihsellik konusunu tarih sahnesine çıaran arka planda da kiliseye karşı aklın bir aktör olarak öne çıkarılması vardır. İnsanın Allah, insan olgusu ve evrene ilişkin bilgisini kontrol eden ve kontrol gücünü elinde tutarak paylaşmayan kilisenin bu otoritesini bazı tarihsel gelişmelerin zayıflatması kilisenin sorgulanmasıyla neticelenmiş ve akıl, kiliseye karşı görece bir üstünlük sağlayarak bilginin kontrolünde pay sahibi olmuştu. Fakat iki asır geçmeden aklın kontrol ettiği bilginin hayata yansımalarıyla değerler sisteminde, özellikle de ahlak alanında ortaya çıkan olumsuz sonuçlar aklın sorgulanması sürecine girmesiyle sonuçlanarak tarihsel akıl, ya da aklın tarihselliği düşüncesinin doğuşuyla sonuçlanmıştı. İşte bu aşamadan itibaren başlayan tarihsellik tartışmaları, akıl ve aklın mahiyeti, dolayısıyla insanın mahiyeti konusu etrafında dönen tartışmalardır.

Batı dünyasında Almanya merkezli olarak XVIII. yüzyılda başlayan bu fikri hareketlilik, XIX. yüzyılın 'Tarih Yüzyılı' olarak isimlendirilmesinden de anlaşılacağ 1 gibi, zengin bir muhteva kazanmıştı. Bu zengin düşünsel muhteva, aklın tarihselliği yanında akıl tarih ilişkisi ve askeri alandan düşünsel alana, sanat eserlerine kadar 
aklın hasılası olan tarihsel olguların anlaşılması dolayımındaki meseleleri yeniden ele alarak sorgulamaya başlamıştı. Bu felsefi sorgulama ile, özellikle anlama/yorumlama, özne-nesne ve tarih, tarih bilinci, tarih yazımı gibi konular öne çıkmaya başlamıştı.

Akıl ve bilimin egemenliğinin ilan edildiği bir önceki dönemde revaç bulan akılcı, aydınlanmacı ve pozitivist felsefelerde insan, varlığ1 ve tarihi anlama konusunda kudretli bir özne olarak tasarlanmış ve kabul edilmişti. Bu öznenin kudreti, 'salt akıl' ile temellendirilmekteydi. 'Tabula Rasa' gibi tasvir edilen salt akıl, tarihsel etkilerden muaf ve koşullanamayan bir güç olarak tasarlandığından, insanın tarihi anlamaya dair her hangi bir kısıtının olmadığ1 düşünülmekteydi. Fakat gelişen bu süreçte var sayılan böyle bir aklın, sanal bir vehimden öte bir şey olmadığı kabul edilmeye başlanmıştı. Aklın tarihselliğini kabul etmenin, anlam diye isimlendirilen hasılanın tarihselliği manasına geldiği, gün geçtikçe daha çok taraftar toplamaktayd.

Öte yandan Batı düşünce dünyası XVIII. yüzyıldan itibaren pozitivizmin etkisinden uzaklaşmaya çabalarken, İslam dünyası bu gelişmelerden habersiz bir bir şekilde modernizm dalgasıyla birlikte pozitivizmin etkisi altına girmeye başlıyor, pozitivizme bir üst akıl gibi sarılmaya meylediyordu. İşte Batı'nın düşünce dünyasından atmaya çalıştı̆̆ı bu geç pozitivizm, halen İslam dünyasının eğitim sistemlerinin temel zemini olarak insan tarih ilişkisini belirlemeye devam etmekte, düşünce dünyasını şekillendirmektedir.

Gelişen Batı dünyası karşısında her alanda gerilemeye başlayan İslam dünyası ilk defa tehlikeyi hissediyor, yeni bir bakışa, bir kurtuluş iksirine ihtiyacı olduğunu fark ediyordu. İslam dünyasının düşünen kafaları, ulema ve entelektüeli, bu kurtuluş reçetesinin İslam'ın özüne, dolayısıyla kaynaklarına dönülerek bulunulacağına inaniyorlardı. Onlar bir taraftan daha önce kendilerini bir medeniyet seviyesine getiren İslam'ın ve hassaten de İslam'ın temel kaynağı olan Kur'an'ın, içerisine düştükleri bu kaostan çıkmak için kendilerine yol göstereceğine inanırlarken diğer taraftan da bu reçetenin modern Batı'da bulunduğuna ilişkin bir şuuraltı ile hareket ediyorlardı. Bu paradoksal durum ise onları Batı medeniyetinin temelinde yer alan felsefeye yönlendirmekteydi. Aslında kurtuluşun somutlaşmış, tecessüm etmiş hali bizzat Batı idi. O halde Batı ile İslam arasında bir yol bulmak gerekmekteydi. Bu ise Oryantalizmin açtığ yolda İslam'ın temel metinlerinin yeniden yorumlanması demekti. 
İşte bu aşamadan sonra İslam metinlerinin yeniden Batılı bir vizyonla yorumlanmasıyla yeni bir teoloji dönemi başlamış oldu. Bu bakımdan her biri birer kurtuluş projesi olan bu okumaların tamamına "kurtuluş teolojisi" ismini koymak hata olmaz.

Ne var ki Kur'an'ın dünyevî bir kurtuluş kitabı olarak okunmaya başlanması, onu asırlardır maruz kalmakta olduğu nesneleşme sürecinden araçsallaştırma sürecine doğru evirmekteydi. Bu süreç, Kur'an'ı zihin kurucu ve hayata yön veren konumundan, insan zihninin ihtiyaçlar bağlamında yorumlayarak yönlendirdiği bir konuma indirgemekteydi. Çünkü bu durumda Kur'an, biraz önce geçtiği gibi artık ümmetin dünyevî kurtuluş ve terakkisinin iksirini derununda saklayan, bunun için de yeniden yorumlanması gereken bir kitap olarak görülmeye başlanmıştı. Aynı zamanda bu durum, asırlardır süren yorum faaliyeti ve tekniğinin de sorgulanmasını ve bir tarafa bırakılarak yeni yorum metotlarının geliştirilmesini gerektirecekti.

İşte dünyevî kurtuluşun Kur'an'da, onun şu ana kadar yapılmamış olan yeni yorumunda olduğuna inanan bazı modern dönem İslam bilginleri, yeni metotlarla yeni tefsir türleri geliştirdiler. Bu meyanda onun doğru manasını anlamak için ilk muhatapların yaşadıkları gibi Kur'an'ın inzal kronolojisine göre okunması ile vücut bulan nüzûl sırasına göre meal ve tefsirler ${ }^{1}$ yanında ilmî, içtimaî ve konulu tefsir türleri ortaya çıktı.

Özellikle Osmanlı dönemi “terakki” tartışmalarında görüldüğü gibi, dinin hurafelere bulanmış olduğu ve bunun Kur'an'ın gerçek anlamını perdelemesi neticesinde ortaya çıkan yanlış din telakkisinin insanları atalete sürükleyerek geri kalmalarına sebep olduğu fikri, Kur'an'ın modern istihdamında yeni bir çığır açarak Kur'an'ın sadece Kur'an'la tefsiri şeklindeki tefsir akımını başlatmıştır. Gerçi sahabe döneminden itibaren ayetlerin ayetle tefsiri bilinen ve makbul bir husustu; fakat bu yeni eğilim, Kur'an dışı dinî bilgi kaynaklarına mesafeli davranmayı, hatta hadis ve tarih kaynaklarını Kur'an tefsirinden tamamen uzaklaştırmayı teklif etmekteydi. "Bize Kur'an yeter" şeklinde özetlenecek bu düşünce/yorum eğilimi, pa-

1 Bk. Muhammed İzzet Derveze, et-Tefsîru'l-Hadis: Nüzul Sirasına Göre Kur'an Tefsiri, çev.: Şaban Karataş vd. (İstanbul: Ekin Yayınları, 1998); Muhammed el-Emîn b. Muhammed el-Muhtâr b. el-Cekenî eş-Şinkitî, Edvấ'ü'l-Beyân fì i'dahi'l-Kur'ân bi'l-Kur'ân (Beyrut: Dârü'l-fikr, 1995). 
radoksal olarak bir taraftan modern müfessirin/yorumcunun geleneksel kültürel alt yapısıyla şekillenirken diğer taraftan da bu alt yapıyı sorgulayan, hatta çoğu noktada reddeden modern sübjektivitesiyle şekillenmekteydi. Mealcilik ve Kur'ancllık (Kur'an'iyyun) olarak bilinen bu akım, sahih ve hurafesiz, dolayısıyla kurtuluşa götürecek bir İslam anlayışının bu metotla kaim olacağını öne sürmektedir.

Kur'an'ın kurtuluş iksirini derununda barındıran bir hazine olduğuna inanan kimi Müslümanlar Kur'an'a adeta saldırarak bu hazineyi bulmak için uğraşmaktadır. Her bir yorumcu, kendi yorumunun yegane sahih yorum olduğunu vehmederek bunun tebliğini yapmak suretiyle etrafında bir "ümmet" meydana getirmeye çalışmaktadır. Daha Kur'an'la karşılaşmadan mağlubiyet tarihselliğinde inşa edilen bu kurtuluş projelerinin her biri, geri kalan Müslümanları açıktan tekfir etmese de ötekileştirmekte ve en hafifinden onları tebliğe muhtaç cahiller olarak kodlamaktadır. Bunun sonucunda her gün yeni bir mezhep ortaya çıkmakta, ümmeti birbirinden ayırarak binlerce parçaya bölmektedir. İslam ümmetini Kur'an'ın doğru yorumu etrafında birleştirme iradesiyle çıılan bu yol, aksine ümmetin her gün biraz daha parçalanarak zayıflamasıyla neticelenmektedir. Çünkü bu yeni tarihsel durumda Kur'an, kendisinden bazı faydaların beklendiği, bu manada kendisiyle ilişki kurulan bir araca dönüşmüş olmaktadır. Kur'an'ın sadece kendisiyle ilişki kurulan bir "şey" haline gelmesi ise, onun "ilişkiyi kuran ve yönlendiren" özelliğini kaybetmesi manasına gelmektedir. ${ }^{2}$

Nitekim Kur'an'ın bu istihdam biçimi, "tarihselcilik" adı verilen kurgusal teoriye de dayanak yapılmış, tarihselciliğin teşekkülü de bu zemin üzerinde vücut bulmuştur. Bu bakımdan Kur'an'ın tarihselliği argümanı üzerinde şekillenen İslam tarihselciliği de bu kurtuluş teolojilerinden birisidir. Modern döneme aidiyeti onun bir modernizm, ya da Fazlurrahman'ın deyimiyle neo-modernizm olarak teşekkülüne yol açarken, bir kurtuluş teolojisi/ideolojisi olmanın muhtemel malûliyetleriyle de malûl olmasını sağlamıştır. ${ }^{3}$

2 Burhanettin Tatar, "Kur'anı Yorumlama Sorunu", Kur'an ve Dil: Dilbilim ve Hermenötik Sempozyumu (Van: Yüzüncü Yıl Üniversitesi İlahiyat Fakültesi Yayınları, 2001).

3 Bu kurtuluş teolojilerinin arka planı için bk. Şevket Kotan, Bir Kurtuluş Teolojisi olarak Tarihselci İslam (A ğrı: İbrahim Çeçen Üniversitesi Ahmed-i Hani Sempozyumu, 5-6 Ekim 2019). 
Tarihselci İslam'ı, İslam modernizmi zemini üzerinde, onun başlatmış olduğu sürecin yeni bir evresi olarak, modernite ile İslam arasındaki uyuşmazlığı giderme iradesinin tezahür biçimlerinden biri diye okumak yanlış olmaz. Zira modernizm, herhangi bir alanda geleneksel hale gelerek yerleşmiş bir takım duygu, düşünce ve olguların, ortaya çıkan yeni şartlara uyum sağlamalarına yönelik gayreti ifade etmektedir. İslam modernizmi ise modern zamanlarda İslam'ın aktüel kılınmasına ve İslam milletinin kurtuluşuna yönelik tez ve projeler için İslam'ın yeniden yorumlanması olarak değerlendirilebilir. İşte bu yorumlardan biri olan "Tarihselci İslam", İslam'ın en radikal yorumlarından biri olmanın yanında aynı zamanda en kapsamlı yorumudur. Çünkü o, İslam'ın temel metinlerinin yeni bir yorumu olmanın haricinde, İslam risaleti ile başlayarak asırlar içerisinde tevarüs yoluyla gelişerek şekillenen İslam ilim geleneğinin temelden eleştirisidir. İslam bilgi sisteminin temel kodlarını değiştirmeyi talep ederek yeni bir bilgi üretim metodu, yeni bir içtihad usulü teklif etmektedir. Keza, Allah tasavvurundan başlayarak risalet, vahiy ve Kur'an hakkında, Kur'an'ın içeriğinin bilgi değeri hakkında eski anlayışları yıkarak yeni bir bakış açısı getirmektedir. Buna göre lafızların arka planında saklı bulunan evrensel mesajlar dışında, Kur'an'daki ifadelerin lafzi manaları ve ihtiva ettiği bilgiler, tarihsel, yerel ve beşerî mahiyetlerdir. Bu ise, İslami kozmolojinin aslında restorasyonu manasına gelmektedir.

Tarihselci İslam'ın "Tarihsellik" haricindeki anahtar kavramları, Batı modernizminin anahtar kavramlarına denk düşmektedir. Zira onun temel sorunsallarını, Orta çağda bilgiyi kontrol eden kiliseye ve dolayımında dine karşı gelişen ve daha sonra modernizm olarak şekillenen protest düşünce hareketinin sorunsalları oluşturmaktadır. Günümüzde Tarihselci İslam'ın gündeme taşıyarak hararetle tartıştı̆̆ vahyin mahiyeti, Kur'an ahkamının geçerliliği, kıssalardaki haberlerin tarihi değeri, kölelik-cariyelik meselesi, mucize, cin vb. gibi konular, Batı rasyonalizminin temel öncülleri ve Hıristiyan alg1 sisteminden hareket eden oryantalistlerin XVII. asırdan itibaren İslam'a yönelik eleştirileriyle Müslümanların önüne gelen konulardı. İslam tarihselcileri bu konuları "tarihsellik" kavramı dolayımında tartışmaya açarak aslında düşüncede bir illüzyon alanı oluşturuyorlar. Zira bu konular oryantalistlerin öne sürmesiyle en azından XVII. asırdan itibaren Müslümanların önüne gelmiş, zamanla Müslüman dünyada yankı bularak 1800'lü yıllarda İslam modernizmi olarak tezahür etmeye başlamıştı. Halbuki bu zamanlarda 
halen Batı felsefesinde tarihsellik kavramı nerdeyse bilinmiyordu. Fazlurrahman'ın "Neo-modernizm" olarak isimlendirdiği tarihselciliğini nispet ettiği tarihsellik kavramının Batı felsefesi içerisinde ortaya çıkmaya başladığı tarih XVIII. asrın sonlarıdır. Bu kavram, modernizmin temelini oluşturan akıl ve bilimciliğin eleştirisi ve rasyonalist-pozitivist felsefelere düşünsel anlamda tepki ile tarih sahnesine çıkmıştır. Dolayısıyla akılcı-nesnelci-aydınlanmacı-pozitivist temellerde teşekkül eden modernizm ile, bu temellerin eleştirisi ve bunların karşıtlığında teşekkül eden tarihselliği bir araya getirmek paradoksal bir durumdur. Bu, tarihsellik fikriyatını, İslam modernizmine felsefi destek sağlayacak şekilde yorumlayarak bundan bir tarihselcilik üretmekle mümkün olmaktadır. Nitekim Fazlurrahman'ın yaptı̆̆ı da bundan başkası değildir.

Tarihsellik, tarih kavramının XVIII. yüzyıldan başlayarak gelişen süreçte kazandığ 1 felsefi anlamına dayanmaktadır. Felsefi dille tarih, insanın yaşadığı bu dünyada varlığa yönelmişliği içinde varlığın ortaya çıkış sürecidir. Bir diğer ifadeyle varlığın, insanın anlama, yorumlama, irade, karar, sorumluluk ve eylem gibi farklı boyutları sayesinde farklı perspektiflerden açığa çıkışıdır. Ancak varlığın açığa çıkışını "tarih" yapan en önemli husus, onun değişmesi, yani başkalaşması veya ötekileşmesidir. Bu nedenle tarihten bağımsız bir insandan da söz edilemez. Çünkü tarih, varlığın insan varlığı ve bilincine etki sürecidir. Bu yüzden tarih, insanın varlığa açıklığ ve onunla etkileşimi esnasında insanın yeryüzüne yerleşme biçimi olarak karşımıza çıkar. İnsanın dünyası dediğimiz şey de, tarih dediğimiz süreç ile kurulur ve insan bilinci ile varlığın karşılıklı etkileşiminin kendisidir. İşte tarihsellik ve insanın tarihsel bir varlık olmasının felsefi izahı budur.

Heidegger öncesi Batı felsefesinde tarihe aidiyet anlamını ifade eden tarihsellik (historicity) kavramı, bir konunun tarihe ilişkin olduğu, bir olayın tarih içerisinde meydana geldiği, o olayın zamansallı̆̆ 1 ve bir tarihte ortaya çıkan fikir, görüş ve değerlerin, söz konusu tarihe aidiyeti ve dolayısıly geçerliliklerinin de dönemsel ve yerel olduğu gibi anlamları ifade etmekteydi. Fakat Heidegger, bu kavramı ontolojik bir içerikle tanımlayarak başta felsefe olmak üzere sosyal bilimler terminolojisinde daha çok insan varoluşunun özsel/fıtri yanını ifade etmek için kullandı. Heidegger felsefesinde tarihsellik, ontolojik manada geçmişe dair bir hafıza taşımakla, yani geçmişi yeniden canlandırma yeteneğine sahip olmakla birlikte bir 
dil ortamı olan dünyada, geleceğe doğru atılmış, yüzü geleceğe dönük, sadece gelecek hakkında tasarımlara sahip, bu nedenle de kendini hep gelecekteki olanaklara doğru aşmaya çalışan insanın bu dünyadaki ontolojik mahiyetini ifade eden bir kavramdır. Heidegger insanı, onun bu dünyada bir varlık olmaklığını, yani tarihselliğini ifade edecek şekilde "Dasein" (dünya içinde, orada-varlık) diye isimlendirir. İşte "tarihsellik", tarihte olmayı ifade etmektedir. Varlığı anlama ise Dasein'in varoluş biçimi olarak daha baştan itibaren varolan ve süregiden bir hadisedir. ${ }^{4}$

Buna mukabil tarihselcilik de (historicism), aslında kavramsal olarak, eleştirel tarih yazıcılığının metodolojik ve epistemolojik ön kabullerinden hareketle, insan doğasını ve toplumu tarih dişı bir perspektiften anlamanın imkânsız olduğunu, insani durum ve meselelere dair bilginin tarihsel bir karakter arz ettiğini ifade etmektedir. Fakat bununla birlikte tarihselcilik, bir kültürün, bir dinin, bir ahlak sisteminin vb. ancak kendi tarihsel bağlamı içinde anlaşılabileceğini ifade eden, aynı zamanda, değişmez, zaman dışı ve evrensel rasyonalite ve ahlak standartlarının var olmadığını ve her biri tarihsel olan bu hadiselerin, evrensel kategoriler olarak görülemeyeceğinin de ifadesidir. ${ }^{5}$

İslam tarihselciliği ise, İslam modernizmi ve tarihselciliğin mecz edilmesiyle ortaya çıkarılan melez bir düşünce sistemidir. Tariselciliğin argümanlarıyla İslam modernizmine hem felsefi bir temel sağlanmış hem de bu fikriyat tarihselcilikle etkili bir jargona kavuşturulmuştur. Bu yeni felsefi jargonla insanın tarihte olmaklığını, yani tarihselliğini tartışma dışı bırakarak, insan tarih münasebetini pozitivist bir tarzda özne-nesne düalizmi üzerinden inşa etmektedir. Buna göre geçmiş tarihe tarihsellik atfedilirken, modern insan tarih üstü bir mahiyet, kudretli özne olarak kurgulanmaktadır. İşte bu kudretli özne, tarihi nesnellikle anlama yetkinliğine sahip olarak tasarlanırken aynı zamanda tarihin üstünde/dışında, yani tarihsiz olarak tasarlanmış olmaktadır.

Tarihselci İslam, insan eylemlerinin tarihselliğini konu ettiği ve Hiristiyanlıktan mülhem yeni vahiy teorisiyle metafizik bir kaynağa sahip olan Kur'an'ı da insan eylemleri kategorisine yerleştirerek ona

4 Bk. Erol Göka vd., Önce Söz Vardı: Yorumsamacılı Üzerine Bir Deneme (Ankara: Vadi Yayınları, 1996), 40.

5 Bk. Doğan Özlem, Tarih Felsefesi (İstanbul: Say Yayınları, 2010); Ahmet Cevizci, Felsefe Sözlüğ̈̈ (İstanbul: Say Yayınları, 2014), 1005. 
böyle muamele ettiği için felsefi düzeyde bir tarihselci modernizm olarak teşekkül etmiştir. Nitekim Fazlurrahman çizgisindeki İslam tarihselciliği de Fazlurrahman'ın metodik yaklaşımlarında olduğu gibi, modern eleştirel tarih yazıcllı̆̆ının metodolojik ve epistemolojik ön kabullerinden hareket etmekte ve Kur'an'a anlamaci/yorumsamacı bir yaklaşım yerine, analitik ve pozitivist yaklaşmaktadır.

Kur'an'a böyle yaklaşmanın en dikkate değer tezahürlerinden biri Kur'an vahyine getirilen yeni izah tarzıdır. İslam ilim geleneğinden farklı olarak Fazlurrahman'a göre vahiy, bir peygamberin kalbine yerleştirilen ilahi bir ruhtur. Bu, adalet üzerine kurulmuş bir düşünce, bir bakış açısıdır. Bu ruh, Peygamberin kalbinde oluşan ve ihtiyaç halinde vahiy şekline dönüşen bir kuvve, bir duyu veya bir araç olarak yorumlanabilir. ${ }^{6}$ Fakat bu ruh, Allah tarafından indirilmektedir. Herhangi bir peygamber bu ruhun rehberliğinde hareket ederek yaşadığı zaman diliminde karşısına çıkan durumları yorumlar, düzenlemeler yapar, bazı kurallar getirir. Dolayısıyla Kur'an, tabiatı itibariyle bu manada tarihsel bir mahiyet olarak ortaya çıkar. Fazlurrahman'a göre Kur'an, Allah'ın tarih içinde cereyan eden durumlara, yani Peygamber'in zamanındaki ahlâkî ve toplumsal durumlara ve özellikle onun zamanında ticaretle uğrasan Mekke toplumunun sorunlarına Peygamber'in zihni vasıtasıyla verdiği ilâhî cevaplar olduğu için, ${ }^{7}$ tarihsel bir metindir.

Fazlurrahman, vahiy görüşüne bir temel bulmaya çalışırken geleneksel İslam vahiy görüşünün yanlış inşa edildiğini savunmakta ve bu yanlışın vebalini Sünni İslam'a yıkmaktadır. O, “Bu durumda $\mathrm{Hz}$. Peygamber ve vahiy ile ilgili olarak, onun şuurunun normal olduğu görüşü, çok daha sonraları Ehl-i Sünnet tarafından teşvik görmüss, ve hatta açıkça ifade edilmiştir. Bunun, vahyin objektifliğini (nesnelliğini) korumak amacıyla Melek'in bir diş, varlığı olduğunu ya da Ses'in dışarıdan geldiğini güvenceye aldığı sanılmıştır. Böyle bir teşebbüs, bize başlangıçta zihnen olgunlaşmamış, gibi görünebilir, ama akidenin teşekkül halinde olduğu bir sırada bu adımı atmak, özellikle de akılcılarla tartışmalara girişmek için zorlayıcı nedenler bulunuyordu. Daha sonraları geniş, ölçüde kabul gören pek çok ha-

6 Fazlurrahman, Ana Konularıla Kur'an, çev.: Alpaslan Açıkgenç (Ankara: Fecr Yayinları, 1987), 198.

7 Fazlurrahman, İslâm ve Çağdaşlık, çev.: Alpaslan Açıkgenç-Hayri Kırbaşoğlu (Ankara: Ankara Okulu yayınları, 2002), 73, 78, 414 
dis ortaya çıktı. Bu hadislerde Hz. Muhammed, Cebrail ile halk huzurunda konuşur bir şekilde gösterilmekte ve Cebrail'in görünüşü, canlı bir şekilde tasvir edilmektedir. Kur'an'daki "Ey Muhammed, apaçık Arap diliyle uyaranlardan olman için, onu (Fazlurrahman'a göre ruhu, ya da vahyi) senin kalbine gönderdik," 8 ayeti bu hususa aykırı düşmekle birlikte, Cebrail'in ve vahyin bir dış, varlığa sahip olduğunu ileri süren bir fikir, Müslümanların genelinin zihninde öylesine kökleşmiştir ki, gerçek durum buna karşı bir küfür teşkil eder. ${ }^{9}$

Kendisine ait bu ifadelerde görüldüğü üzere Fazlurrahman, vahiy hadisesine rasyonel bir izah getirmekte, gaybî bir hadise olan vahiy hakkında dahi nesnelci davranmaktan çekinmeyerek sanki kendisi vahiy almış, bu tecrübeyi yaşamış gibi konuşarak vahiy hadisesini açılamaktadır. İste bu örnek, "tarihselci İslam"ın vahiy hadisesinden başlayarak Kur'an'ı anlamaya pozitivistçe yaklaştıklarını açık bir örneğidir. Halbuki Kur'an'ın açık lafızları böyle bir yoruma imkân vermez. ${ }^{10}$ Nitekim İslam geleneğindeki vahiy anlayışı da risalet tarihiyle birlikte lafza dayalı teşekkül etmiştir.

İslam geleneğinde tarihsel temeli bulunmayan bu vahiy anlay-şının öne çıkarılmasının arkasında pozitivist bakış açısı dışında bir başka neden daha vardır. O da, "tarihselci İslam"ın, Kur'an'ın tarihselliğini temellendirmesi için böyle bir vahiy görüşünün uygun olmasıdır. Çünkü vahyin lafzının yanında içeriğinin de peygamberin ufkuyla kültürel ve tarihsel olarak şekillendiğinin kabulü, Kur'an'1 İslam modernizminin yorum tarzına uygun hale getirmekte ve modernizmin taleplerine meşru bir temel sağlamaktadır. Böylece tarihsel olduğu için mesela İslam hukuku yerine modern çağın ilişki biçimlerine uygun yeni bir hukuk sistemi kurmak dini meşruiyet açsında mümkün olabilecektir. İslam modernizminin Müslümanların sırtında kambur gibi gördüğü ceza uygulamaları, mirasın taksimi, kadının şahitlikte erkekle bir tutulmaması, kölelik ve cariyelik benzeri yüklerden kolaylıkla kurtulunacaktır.

8 eş-Şuara 26/194.

9 Fazlurrahman, İslam, çev.: Mehmet Aydın-Mehmet Dağ (İstanbul: Selçuk Yayınlar1, 1992), 18.

10 el-A'lâ 87/6-7, el-Kiyame 75/16-19, en-Necm 53/1-18. 
Tarihselci İslam'ın tarihsel İslam'dan bu denli temelden uzaklaşması gerçekten dikkate değerdir. Özellikle de tarihselcilerin tarihe o kadar önem atfetmelerine ve Kur'an'ın gerçek anlamını ilk muhatapların anladığıyla özdeşleştirmelerine rağmen, nüzul tarihinde kabul gören mana yerine lafzi mananın arkasındaki evrensel mana diye modern dönemde inşa edilen kurguyu öne çıkararak bunun üzerine esaslı projeler inşa etmelerinin başka bir nedeni olmalıdır. Kanaatimizce bu neden, tarihselciliğin bir kurtuluş teolojisi/projesi olarak geliştirilmiş olmasıdır. Tarihselcilerin metinlerin yorumunda bu kadar zorlamaya gitmeleri, ümmeti kurtarmaya yönelik güçlü iradelerine dayanıyor olmalıdır. Zira tarihselcilik de, Kur'an'ın kurtuluş iksirinin tarihselci yorum metodolojisiyle bulunulacağına kanidir. Tarihselcilere göre, eğer Hz. Peygamber döneminden sonra kaybolmuş olan tarihsellik düşüncesi yeniden geri getirilebilir ve Kur'an bu yöntemle yorumlanacak olursa, onun hayat veren mesajı doğru anlaşılacak, bu da Müslümanların kurtuluşuna vesile olacaktır. Bu nedenle tarihselciler, Kur'an'1 tarihsel yorum yöntemiyle yeni baştan tefsir etmeye çalışıyorlar, eski tefsirlerden de sadece tarihselci yorum yöntemine dayanak olacak malzemeyi alarak yararlanıyorlar. Böylece asırlardır yanlış anlaşılan ilahî kitabın sahih anlamına ulaşılarak buradan ümmet için modern çağda yaşanılabilir bir yaşama modeli çıkarılacaktır.

Tarihselci İslam, ontolojik tarihsellik fikriyatından onun karşıtı durumundaki bir felsefe üretirken (İslam modernizmi) bir köken/nesep sorunuyla yüz yüze gelerek esasında felsefi köken bak1mından tarihsizleşmektedir. Aynı şekilde o, tarihsel İslam'dan koparken de dini köken bakımından tarihsizleşmektedir. Fakat tarihselciler köken ihtiyacının farkında olmalılar ki İslam modernizminin yeni sunumunu tarihsellik jargonuyla yaparak "tarihselci İslam"a felsefi köken inşa etmektedirler. Aynı şekilde bazı dinî ifade tarzlarından ve dini şahsiyetlerin bazı söz ve tasarruflarından seçmeler yaparak da dini köken inşa etmektedirler. Bunun için Hz. Ömer, Şatıbî ve İmam Maturidî gibi isimlerin bazı söz ve tasarruflarını örnek göstererek tarihselciliğe dini köken bulmaya çalışmaktadırlar. Halbuki bu yaptıkları, ideolojik bir inşadan ileri gitmemektedir. Zira bu ve benzeri şahsiyetler, sahih İslam geleneğinin yapı taşlarıdır. İslam geleneği dediğimiz olgu, tarihsel süreç içerisindeki sapmalar bir kenara bırakılacak olursa, bu şahsiyetlerin söz ve tasarruflarının ışığında teşekkül etmiştir. Kaldı ki tarih içerisinde, söz 
konusu dini ifadeler onların ileri sürdükleri gibi anlaşılmış olsaydı o takdirde tarihselciliğe bir karşıt bulmak da zorlanacaklardı.

Tarihselciler, mesela Şatıbi'nin bir bazı ifadelerini tarihselciliğin İslami kökenine delil olarak göstererek tarihselci bir Şatıbi üretirlerken, ilk evvela Şatıbi'nin o adeta reddettikleri İslam geleneği içerisinde bir yere oturduğunu ve temel paradigmasının da tarihselci olmadığını, bam başka bir tarihsel ortamda ve sorunlar çerçevesinde şekillendiğini gözden kaçırıyorlar. Bu da, söz konusu ifadeleri ya anlamadıklarını ya da yanlış yorumladıklarını göstermektedir. Kaldı ki farkında olmasalar da böyle durumlarda çokça eleştirdikleri anakronizme düşüyorlar. Görünen o ki, onlar İslam geleneğinden tarihselci bir gelenek üretmeye çalışıyorlar.

Temel paradigması itibarıyla doğru bulmadıkları İslam ilim geleneğinden tarihselci bir gelenek üretmeye çalışırlarken, tarihsel verilerden taraflı bir seçmecilik yapmaktan hatta bilimsel açıdan kabul edilemez bir istihdam biçiminden kaçınmadıkları görülmektedir. Mesela Hz. Ömer'in, Kur'an'ın açık hükmüne ve Peygamber'in uygulamasina muhalefet ederek Sevad arazilerini savaş gazilerine dağıtmadığı ve Kur'an'ın müellefe-i kulûb'a zekat mallarından pay verilmesi hükmünü kaldırarak uygulamadığını örnek göstermelerindeki durum tam da böyledir. Bu konuda yapılan bilimsel araştırmalar, söz konusu hadiselerin onların anlattığı gibi gerçekleşmediğini ortaya çıkarmakta, Hz. Ömer'in İslam fıkhına aykırı her hangi bir tasarrufta bulunmadığını göstermektedir. ${ }^{11}$ Nitekim İmam Şatıbî ve diğer ulemaya dair yaptıkları okumalar da böyledir. İslam geleneğinin böyle okunmasıyla tarihselciliğe İslami bir köken bulmaya çalışılması, İslam ilim müktesebatının tarihselci teorinin meşruiyeti için istihdam edilmesinden başka bir şey değildir. İslam ilim geleneğinin böyle bir istihdamı, Fazlurrahman'dan başlayan bir gelenek olarak günümüzde de devam ettirilmektedir. Belki de Fazlurrahman bunu kendisine yönelik şiddetli eleştirilere karşı bir kalkan olarak kullanmıştı. Fakat göründügü kadarıyla günümüzdeki tarihselciler, İslam'ın özünde tarihselci bir din olduğuna itikat ettiklerinden bunu yapiyorlar.

11 Bk. Saffet Köse, “Hz. Ömer'in Bazı Uygulamaları Bağlamında Ahkamın Değişmesi Tartı̧̧malarına Bir Bakış", İslam Hukuku Araştırmaları Dergisi 7 (2006): 13-50. 


\section{Sonuç}

Sonuç olarak "tarihselci İslam", İslam modernizminin yeniden üretilerek Batı'daki tarihsellik tartışmalarında kullanılan ve pozitivist olarak değerlendirilen bazı argümanlar ve jargonlarla yeniden üretilmesi olarak gözükmektedir. Nitekim tarihselciliğin temel meselelerinin çoğu, İslam hukukunda yer alan kısas, el kesme, kadının şahitliği ve mirasın taksimi gibi İslam modernizminin meseleleridir.

Tarihselci İslam, tarihsellik tartışmalarının jargonunu kullanarak felsefi, İslam İlim geleneğini istihdam ederek de dini bir temel bulmaya çalışmaktadır. Halbuki ontolojik tarihsellik, tarihte olmayı ontolojik bir durum olarak göz önüne getirerek ve 'tarihte olma' çerçevesinde tartışmalar sürdürerek tarihte olmanın felsefi zeminini inşa ederken, İslam fikhı da klasik döneminde, yaşayan bir organizma halindeki İslam ümmetinin sorunsalları dolayımında tarihin içerisinde teşekkül etmiştir. Bu iki olguda da tarihte olmak temeldir. Halbuki "tarihselci İslam"ın, her iki olgunun müktesebatını istihdam ederken de onlara mensubiyeti dolaylıdır. Zira bu düşünce felsefi olarak ontolojik tarihselliğin karşıt felsefi sistemlerine mensup iken, dini bakımdan da geleneği olmayan yepyeni bir olgudur.

Modern dönemde ortaya çıkan diğer İslami söylemler gibi "tarihselci İslam"ın da bir "kurtuluş teolojisi" olması, onun İslam ilim geleneğini, özellikle de Kur'an'1, tarihte örneği olmayan bir okuyuşa zorlamakta ve karşıtı olduğu İslam geleneğinden tarihselci bir teori inşa etmeye sevk etmektedir. Bu nedenle tarihselci teori, bilimsellik disiplininden uzaklaşarak ideolojik bir görünüme bürünmektedir. Tarihselcilerin, temelden karşıt oldukları İslam ilim geleneğinin kuruluşundaki temel taşları niteliğindeki Hz. Ömer, İmam Şatıbî, İmam Malik ve diğer benzeri şahsiyetlerden seçmeler yaparak onlardan tarihselci figürler çıkarmaya çalışmak gibi bir paradoksun içerisine düşmelerinin arkasındaki saik de bu olmalıdır.

\section{Kaynakça}

Cevizci, Ahmet. Felsefe Sözlü̈̆̈̈. İstanbul: Say Yayınları, 2014.

Derveze, Muhammed İzzet. et-Tefsîru'l-Hadis: Nüzul Strasına Göre Kur'an Tefsiri. Çev. Şaban Karataş vd. İstanbul: Ekin Yayınları, 1998.

Fazlurrahman. Ana Konularıla Kur'an. Çev. Alpaslan Açıkgenç. Ankara: Fecr Yayınları, 1987.

Fazlurrahman. İslâm ve Çă̆daşlık. Çev. Alpaslan Açıkgenç-Hayri Kırbaşoğlu. Ankara: Ankara Okulu Yayınları, 2002. 
Fazlurrahman. İslam. Çev. Mehmet Aydın-Mehmet Dağ. İstanbul: Selçuk Yayınları, 1992.

Göka, Erol, vd., Önce Söz Vardı: Yorumsamacılı Üzerine Bir Deneme. Ankara: Vadi Yayınları, 1996.

Kotan, Şevket. Bir Kurtuluş Teolojisi olarak Tarihselci İslam. Ağrı İbrahim Çeçen Üniversitesi Ahmed-i Hani Sempozyumu, 5-6 Ekim 2019.

Köse, Saffet, “Hz. Ömer'in Bazı Uygulamaları Bağlamında Ahkamın Değişmesi Tartışmalarına Bir Bakış". İslam Hukuku Araştırmaları Dergisi 7 (2006).

Özlem, Doğan. Tarih Felsefesi. İstanbul: Say Yayınları, 2010.

Şinkitî, Muhammed el-Emîn b. Muhammed el-Muhtâr b. el-Cekenî. Edvâ'ü'l-Beyân fî̀ i'dahi'l-Kur'ân bi'l-Kur'ân, Beyrut, Dârü'l-fikr, 1995.

Tatar, Burhanettin. "Kur'anı Yorumlama Sorunu". Kur'an ve Dil: Dilbilim ve Hermenötik Sempozyumu. Van Yüzüncü Yıl Üniversitesi İlahiyat Fakültesi Yayınları, 2001. 